\title{
Utilization of detritus and bacteria as food sources by two bivalve suspension-feeders, the oyster Crassostrea virginica and the mussel Geukensia demissa
}

\author{
Christopher J. Langdon ${ }^{1}$, Roger I. E. Newell ${ }^{2}$ \\ ${ }^{1}$ Hatfield Marine Science Center, Oregon State University, Newport, Oregon 97365, USA \\ ${ }^{2}$ Horn Point Environmental Laboratories, Center for Environmental and Estuarine Studies, University of Maryland, Box 775 , \\ Cambridge, Maryland 21613, USA
}

\begin{abstract}
The concentration and composition of suspended particulate food available to estuarine suspension-feeding bivalve molluscs varies temporarily and spatially. Non-algal food sources may be important to suspension-feeders when algal concentrations are seasonally low or where there are high concentrations of suspended detrital material and bacteria, as found within marshes. We carried out a series of laboratory experiments and field measurements to determine to what extent 2 common estuarine bivalve molluscs, the oyster Crassostrea virginica and the ribbed mussel Geukensia demissa, could utilize cellulose and bacteria from Canary Creek marsh, Delaware, USA. Endogenously produced extracellular cellulases of the oyster depolymerized ingested cellulose to soluble oligomers. Subsequent intracellular cleavage of the oligomers to glucose was limited. The oyster absorbed carbon from refractory cellulosic material with an efficiency of only $3 \%$. In contrast, the ribbed mussel absorbed carbon from the same cellulosic material with an efficiency of $9 \%$ and this increased to $14 \%$ if mussels were subjected to a $6 \mathrm{~h}$ exposure $/ 6 \mathrm{~h}$ submergence cycle, a typical exposure regime for this intertidal species. We estimated that suspended cellulosic carbon in Canary Creek marsh during summer could supply $0.7 \%$ and $8.6 \%$ of the respiratory carbon requirements of subtidal oysters and intertidal mussels, respectively. In laboratory feeding experiments, colonization of refractory cellulosic food material by cellulolytic bacteria isolated from the marsh resulted in the oyster indirectly assimilating cellulosic carbon with an efficiency of $10 \%$. The oyster was able to filter free, unattached bacteria from suspension with an efficiency of only $5.0 \%$, compared with an efficiency of $15.8 \%$ for the ribbed mussel. We estimated that both unattached and attached bacteria combined in Canary Creek marsh during summer provide only $5.5 \%$ of the oysters' metabolic carbon requirements but could provide $31.0 \%$ of an intertidal mussel's metabolic carbon requirements. Experiments with ${ }^{15} \mathrm{~N}$ labelled bacteria indicated that attached bacteria associated with the breakdown of cellulosic material could mediate the flow of dissolved inorganic nitrogen from seawater to the oyster We estimated that unattached and attached bacteria in Canary Creek marsh during summer could contribute $26.7 \%$ and $70.6 \%$ of the metabolic nitrogen requirements of subtidal oysters and intertidal mussels, respectively. These results indicate that in this marsh, utilization of bacteria as a food source could make a significant contribution during the summer to the nitrogen requirements of the oyster and to the carbon and nitrogen requirements of the mussel. However, cellulosic detritus and bacteria do not appear to fully meet the requirements of these bivalve species for carbon and nitrogen and utilization of other food sources is required, such as phytoplankton, nanozooplankton or non-cellulosic particulate and dissolved organic matter
\end{abstract}




\section{INTRODUCTION}

Marine bivalve molluscs are an important and often dominant component of the macroinvertebrate biomass of coastal and estuarine ecosystems. Suspension-feeding bivalve molluscs often form an important link between the water-column and benthos by filtering suspended particles from the water column and producing large amounts of biodeposits which become incorporated in sediments. Populations of the ribbed mussel Geukensia demissa inhabiting marshes have been estimated to filter a daily volume of water in excess of the tidal volume of the marsh (Jordan \& Valiela 1982). Kuenzler (1961) reported that up to one third of suspended particulate phosphorus was removed by mussels inhabiting a Georgian (USA) salt marsh. A major fraction of this filtered material was sedimented as biodeposits, thereby conserving this nutrient and other materials within the marsh

Although there is a considerable body of information on bivalve nutrition, primarily based on laboratory studies of animals fed on algal diets (see reviews by Epifanio 1982, Webb \& Chu 1982) there is little known about the effects of variation in food availability and quality on the nutritional status of bivalves in the natural environment. Information on the relative importance of phytoplankton and material derived from marsh plants in the nutrition of estuarine bivalves has been obtained from measurements of stable isotope ratios of carbon, sulfur and nitrogen (Montague et al. 1981, Peterson et al. 1985, 1986). However, although such tracer techniques enable the elemental origin of food material to be identified, they yield little information on the exact pathways and mechanisms that enable the material to be assimilated by bivalves in their natural habitat.

In this paper we briefly review temporal and spatial heterogeneity in food available to estuarine and marshinhabiting suspension feeders, such as the oyster Crassostrea virginica and the ribbed mussel Geukensia demissa. In addition, we present results of a series of experiments carried out in our laboratories, some of which have been previously published (Newell \& Langdon 1986, Kreeger et al. 1988. Crosby et al. 1989, in press), that were designed to detemine utilization of cellulosic detritus and bacteria as food sources by these bivalve species in a marsh environment. The potential importance of cellulosic detritus and bacteria in meeting the carbon and nitrogen requirements of mussels and oysters is then discussed.

\section{VARIATION IN FOOD AVAILABILITY}

Phytoplankton is considered to be a major source of nutrition for suspension-feeding molluscs. Seasonal cycles in primary production of cold temperate waters associated with changes in temperature and light intensity are commonly observed (Eppley 1972). However, the winter minimum of phytoplankton production often has little effect on bivalve populations because many bivalve species are quiescent during this season due to low water temperatures (Newell 1979). In addition, bivalve species commonly accumulate nutrient reserves during periods of phytoplankton abundance which support maintenance metabolism and gametogenesis during these predictable periods of reduced food availability (Bayne 1976, Sastry 1979).

Variation in spring and summer primary production between years may have more significant repercussions on production of populations of suspensionfeeders than the winter minimum. For example, in Broad Creek, Maryland (USA), a sub-estuary of Chesapeake Bay, high spring rainfall (March through May 1983) caused an abrupt decrease in salinity in spring 1983 (Fig. 1a). This high rainfall resulted in extensive flushing of phytoplankton from Broad Creek and the reduced salinity depressed autochthonous primary production. As a consequence, chlorophyll a concentrations between March and June (Fig. 1a) were an order of magnitude lower than during the same period in 1982 (Berg \& Newell 1986). However, despite this lack of phytoplankton in 1983, spring concen-
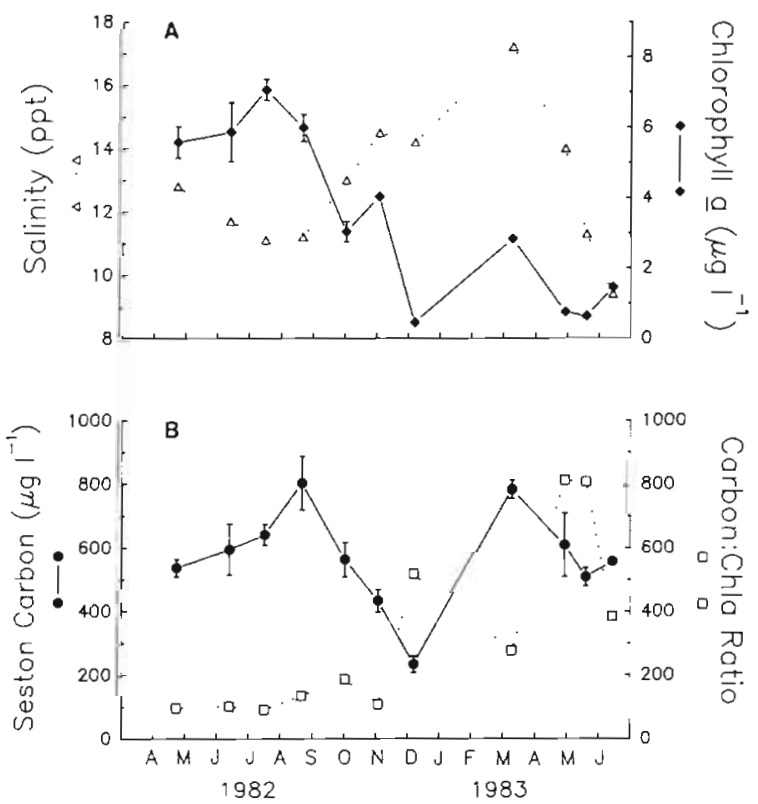

Fig. 1 Seasonal vanation in seston composition at Broad Creek, Maryland. (A) Phytoplankton abundance $(\bullet-)$, measured as chlorophyll a concentration $\left(\mu \mathrm{g} \mathrm{l}^{-1}\right)$, and salinity $(\ldots \cdots),(B)$ Concentration of total organic carbon $\left(\mu g l^{-1} ; \bullet-\bullet\right)$ and the ratio of organic carbon to chlorophyll a ( $\cdots \cdot \cdots)$. Values are means $\pm 1 \mathrm{SD}(\mathrm{n}=3)$. For mean chlorophyll and carbon values without standard deviations error bars are smaller than the plotted symbol. Data from Berg \& Newell (1986) 
trations of total particulate organic carbon did not differ between years (Fig. 1b) indicating greater allochthonous inputs of carbon, or perhaps resuspension of sedimentary organic material, in 1983 than in 1982 (Berg \& Newell 1986). High concentrations of suspended non-algal organic matter in spring 1983, Broad Creek, are also indicated by relatively high carbon to chlorophyll ratios (Fig. 1b). Values of ca 100 for the ratio of total suspended particulate carbon to chlorophyll $a$ indicate that carbon is mainly associated with living phytoplankton cells, whereas values greater than 100 are indicative of the presence of higher proportions of non-living detrital carbon (Zeitzschel 1970). In Broad Creek the ratio was ca 100 throughout 1982. In contrast, carbon to chlorophyll ratios were much higher in 1983, reaching 800 in spring (April and May), indicating that the majority of suspended carbon was not from living phytoplankton but instead associated with detritus. Oysters inhabiting Broad Creek during spring 1983 would benefit if they were able to utilize detrital carbon in order to meet seasonally higher carbon demands associated with gametogenesis and growth.

In addition to seasonal and yearly variation in seston composition and concentration within one estuarine habitat, significant differences also occur between
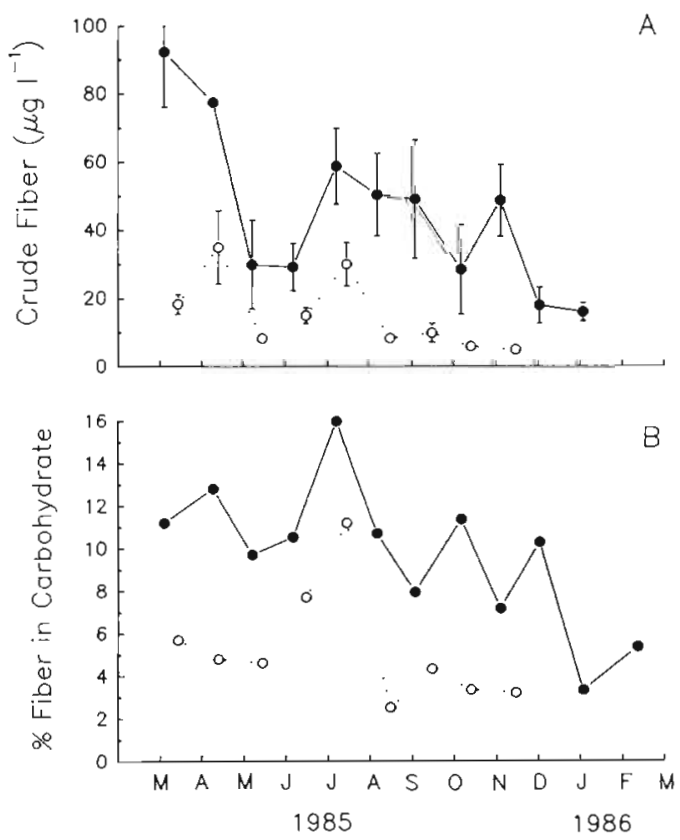

Fig. 2. Seasonal variation in seston composition at Broad Creek, Maryland ( $\cdots \circ$; Crosby et al. in press), and Canary Creek marsh, Delaware (- Kreeger et al. 1988). (A) Concentration of total crude fiber in the seston $\left(\mu \mathrm{g} \mathrm{l}^{-1}\right)$. Values are means $\pm 1 \mathrm{SD}(\mathrm{n}=3)$. For means without standard deviations error bars are smaller than the plotted symbol. (B) Percentage contribution of crude fiber to the total carbohydrate fraction of the seston habitats, in part due to the magnitude and composition of allochthonous carbon inputs. For example, the composition and concentrations of suspended detrital material in a system with limited tidal wetlands, such as Broad Creek, Chesapeake Bay, differ from those of Canary Creek, a sub-estuary of Delaware Bay, which drains extensive marshland dominated by the marshgrass Spartina alterniflora. Total concentrations of crude fiber, estimated by the acid/alkali extraction procedure of Strickland \& Parsons (1972), were considerably higher in Canary Creek than in Broad Creek (Fig. 2a). Furthermore, a higher proportion of total suspended particulate carbohydrate was made up of crude fiber in Canary Creek than in Broad Creek (Fig. 2b).

The high concentrations of crude fiber in the seston of Canary Creek, compared with those of Broad Creek, were probably due to inputs of lignocellulosic detritus from decomposing Spartina alterniflora from the surrounding marshland. Living $S$. alterniflora is composed of 70 to $82 \%$ carbohydrate by dry weight (Squiers \& Good 1974, Smith et al. 1979) and up to $99 \%$ of the carbohydrate fraction is made up of cellulosic material (McIntire \& Dunstan 1976, Maccubbin \& Hodson 1980). Much of the decomposition and fragmentation of marshgrass lignocellulosic material occurs within the marsh (Smith et al. 1979, Benner et al. 1984, Newell et al. 1985), but some of the litter may be exported to adjacent estuaries during periods of high tides, unusual storms (Pickral \& Odum 1976) or as a result of ice rafting (Heinle \& Flemer 1976).

The concentration of cellulosic material in Canary Creek was determined by digesting filtered suspended material with cellulases and measuring the total release of glucose (Kreeger et al. 1988). Cellulose concentrations as high as $165 \mu \mathrm{g} \mathrm{l}^{-1}$ were found in winter (December to March), with an average annual concentration of $78 \pm 47$ ( $1 \mathrm{SD}, \mathrm{n}=3) \mu \mathrm{g} \mathrm{l^{-1 }}$ (Fig. 3). About

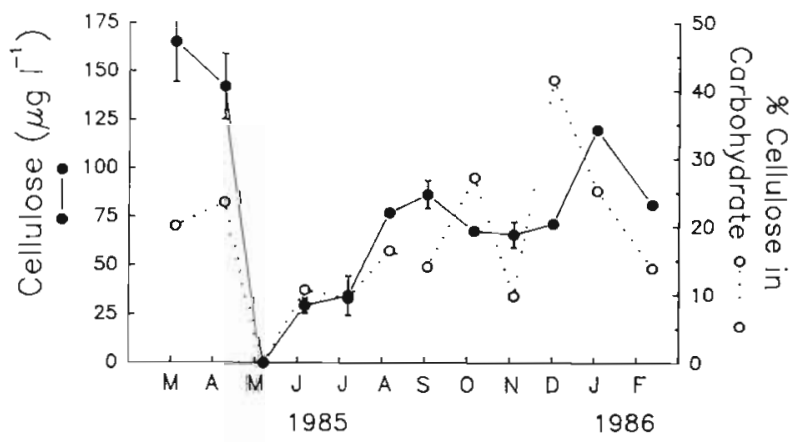

Fig. 3. Seasonal variations in cellulose concentration in the seston (mean $\pm 1 \mathrm{SD}[\mathrm{n}=3] ; \mu \mathrm{g} \mathrm{l}^{-1} ; \bullet \bullet$ ) and the percentage contribution of cellulose to the mean total carbohydrate content of the seston at Canary Creek marsh, Delaware $(0 \cdots 0)$. For mean cellulose values without standard deviations error bars are smaller than the plotted symbol. Data from Kreeger (1986) 
$25 \%$ of the total particulate carbohydrate in the seston was made up of cellulose in the spring and fall, with lower proportions occurring in summer (Fig. 3).

The average total concentration of bacteria in the Canary Creek marsh over a 10 mo period (Fig. 4) was $4.92 \pm 1.20(\mathrm{n}=30) \times 10^{6}$ bacteria $\mathrm{ml}^{-1}$ (Kreeger 1986). Bacterial concentrations in Delaware Bay adjacent to Canary Creek inlet were measured during the same period by Coffin \& Sharp (1987). The mean total bacteria concentrations for months when Canary Creek and the main stem were both sampled were $4.80 \pm$ $1.42(\mathrm{n}=30)$ and $3.87 \pm 1.78(\mathrm{n}=12) \times 10^{6}$ bacteria $\mathrm{ml}^{-1}$, respectively, indicating that the average concentration of bacteria in Canary Creek was $24 \%$ higher than in Delaware Bay. An average of only $3.6 \% \pm$ $1.2 \%(\mathrm{n}=30)$ of suspended bacteria in Canary Creek was attached to seston particles, sampled over a 10 mo period (Kreeger 1986).

In summary, estuarine bivalves inhabit environments that exhibit temporal and spatial variability in concentration and biochemical composition of suspended particulate food resources. Non-algal foods, such as crude fiber, cellulose and bacteria may be important sources of nutrition to bivalves during periods of low phytoplankton abundance as well as in habitats receiving significant inputs of allochthonous material from marshes, such as Canary Creek, Delaware.

\section{MARSHGRASS DETRITUS AS A FOOD SOURCE}

The role of detritus derived from vascular plants, such as Spartina alterniflora, in the nutrition of suspension-feeding bivalves is equivocal. Attempts to culture the scallop Argopecten irradians (Kirby-Smith 1976) and the mussel Mytilus edulis (Williams 1981) on marshgrass detritus alone have been unsuccessful, although it is not clear from such studies whether poor growth was due to nutritional deficiencies of the detritus or due to its poor digestibility. Stuart et al. (1982) demonstrated that the mussel Aulacomya ater could digest and assimilate up to $50 \%$ of detritus prepared from kelp. However, detritus from such macroalgae is more readily digestible than detritus from S. alterniflora (Findlay \& Tenore 1982).

Stable isotope analyses have been used extensively to study the ability of natural populations of molluscs to utilize detritus derived from Spartina alterniflora. Haines and co-workers (see review by Montague et al. 1981) demonstrated that detritus originating from $S$. alterniflora was important in the nutrition of some species of invertebrates living within the marsh, but not important to Crassostrea virginica inhabiting creeks draining marshland. Peterson et al. (1985, 1986) reported that the diet of populations of the American

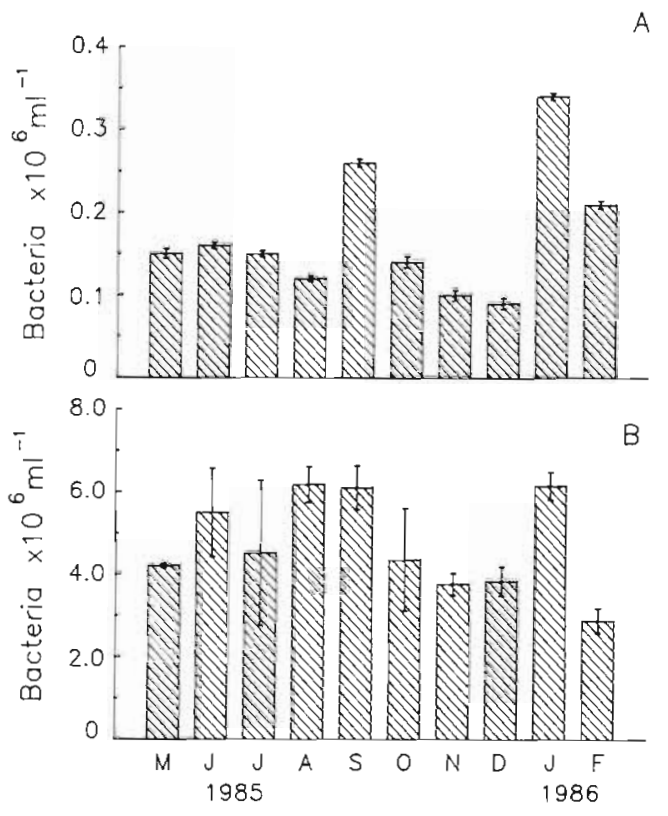

Fig. 4. Seasonal variations in concentration of bacteria (mean $\left[ \pm 1 \mathrm{SD}\right.$ ] cells $\mathrm{ml}^{-1}$ ). (A) Bacteria attached to seston particles in Canary Creek marsh. (B) Free, non-attached bacteria in Canary Creek marsh, Delaware. Data from Kreeger (1986)

oyster and ribbed mussel consisted of both phytoplankton and detritus originating from $S$. alterniflora. Mussels in the interior of the Great Sippewissett marsh had carbon and sulfur isotopic signatures which indicated that as much as $80 \%$ of their diet originated from S. alterniflora. Conversely, ribbed mussels living at the mouth of the creek draining the marsh only obtained about $40 \%$ of their nutrition from S. alterniflora (Fig. 5).

Using the methods described by Peterson et al. (1986) we determined carbon and sulfur isotopic signatures for ribbed mussels at 3 sites along a transect

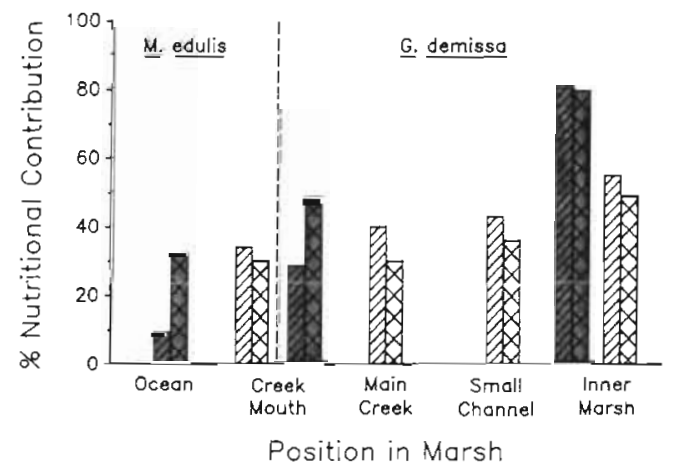

Fig. 5. Estimated percent contribution, based on stable isotope ratios (Fig. 6), of material derived from Spartina alterniflora to the nutrition of the blue mussel Mytilus edulis and the ribbed mussel Geukensia demissa. Estimates based on sulfur (diagonal slashes) and carbon (broad cross hatching) ratios. Data for Great Sippewissett Marsh from Peterson et al. (1985) indicated by shaded bars, and data for Canary Creek from this study indicated by non-shaded bars 


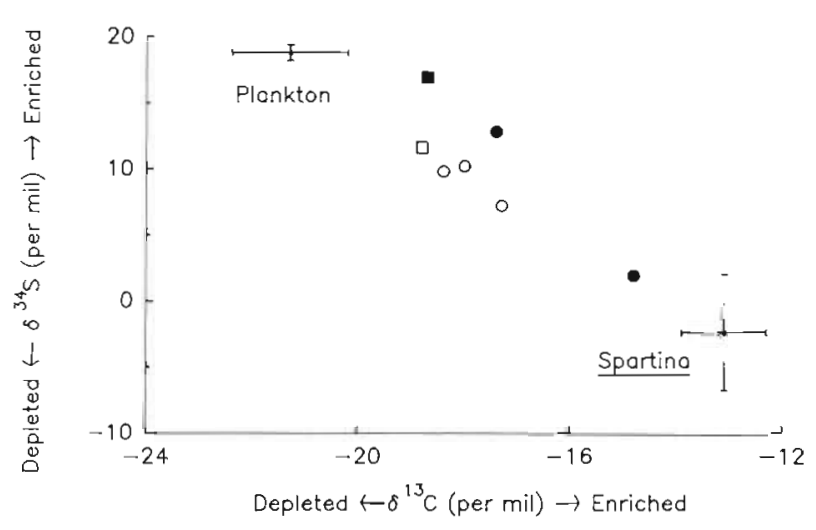

Fig. 6. Isotopic signatures for Geukensla demissa (0) and Mytilus edulis ( $\square$ ) collected along a transect through Canary Creek marsh, with ${ }^{34} \mathrm{~S}$ plotted as a function of ${ }^{13} \mathrm{C}$. Data for $G$. demissa $(\bullet)$ collected along a transect in Great Sippewissett Marsh and an open ocean population of $M$. edulis ( $\mathbf{}$ ) from Peterson et al. (1985). Each of these points represents pooled samples of 10 to 200 individuals. Data for the isotopic signatures for Spartina and phytoplankton are taken from Peterson et al. (1985). Bars are means $\pm 1 \mathrm{SD}$

from the mouth of Canary Creek to the innermost region of the marsh (Fig. 6). All stable isotope analyses were performed by the Ecosystem Center, Marine Biological Laboratory, Woods Hole. Results indicated that Spartina alterniflora provided ca $50 \%$ of the carbon and sulfur in tissues of mussels living in the inner parts of Canary Creek marsh but less than $40 \%$ of those elements for mussels living at the mouth of the creek (Fig. 5). These differences in the importance of $S$. alterniflora as a food source for mussels inhabiting various parts of Canary Creek marsh were not as pronounced as those reported by Peterson et al. (1986) for spatially separated populations of mussels from the Great Sippewissett marsh (Fig. 5). Blue mussels Mytilus edulis living at the confluence of Canary Creek and Delaware Bay had an isotopic signature indicative of them obtaining ca $30 \%$ of their nutrition from material derived from S. alterniflora (Fig. 6), suggesting export of detritus of $S$. alterniflora from the mouth of Canary Creek marsh into Delaware Bay.

Stable isotope studies are useful in that they provide an integrated measure of the relative contributions of elements and food to consumers inhabiting ecosystems but they provide little information on the consumer's feeding behavior and physiology that may explain observed isotopic signatures.

\section{UTILIZATION OF CELLULOSE}

A second approach in assessing the potential importance of marshgrass detritus in the nutrition of bivalve suspension-feeders is to produce chemically defined, isotopically labelled detrital material, and to determine the ability of bivalves to utilize this material under experimental conditions. We have used results from this kind of experiment, in conjunction with environmental measurements of the concentration of suspended cellulose, to estimate the importance of this food source in the nutrition of bivalves inhabiting Canary Creek marsh.

Radiolabelled Spartina alterniflora, grown in an atmosphere enriched with ${ }^{14} \mathrm{CO}_{2}$, was subjected to grinding and acid/alkali extraction to produce lignocellulosic material $<20 \mu \mathrm{m}$ in particle size (Newell \& Langdon 1986). The composition of the prepared lignocellulosic material was characterized by a combination of chemical and enzymatic methods to determine the distribution of ${ }^{14} \mathrm{C}$ among biochemical fractions. Ninety-two percent of ${ }^{14} \mathrm{C}$ was present in the polysacharide fraction, and $85 \%$ of this fraction was digested by cellulases and, therefore, potentially biologically available to consumers (Newell \& Langdon 1986). The remaining ${ }^{14} \mathrm{C}$ label was present in lignin $(7.7 \%)$, and lipid $(0.1 \%)$ fractions.

In vitro enzymatic studies (Newell \& Langdon 1986) indicated that extracts of the oyster's style were able to break down both particulate amorphous cellulose and the prepared ${ }^{14} \mathrm{C}$-labelled Spartina alterniflora material to soluble oligomers (Fig. 7) by the action of endogenously produced $\beta-1,4$-glucanase $\left(C_{x}\right.$ cellulase $)$. However, extracellular $C_{1}$-cellulase, that breaks down crystalline cellulose, was not detected in style extracts (Fig. 7). The absence of glucose release from cellobiose together with the low rate of glucose production from partially digested amorphous cellulose and $S$. alterniflora (Fig. 7), indicated that $\beta$-glucosidase (cellobiase) was not present in the style. However, complete intracellular breakdown of amorphous cellulose to glucose can probably occur in Crassostrea virginica because both $\beta$-1,4-glucanase activity (Brock et al. 1986) and $\beta$-glucosidase (cellobiase) activity (Mayasich

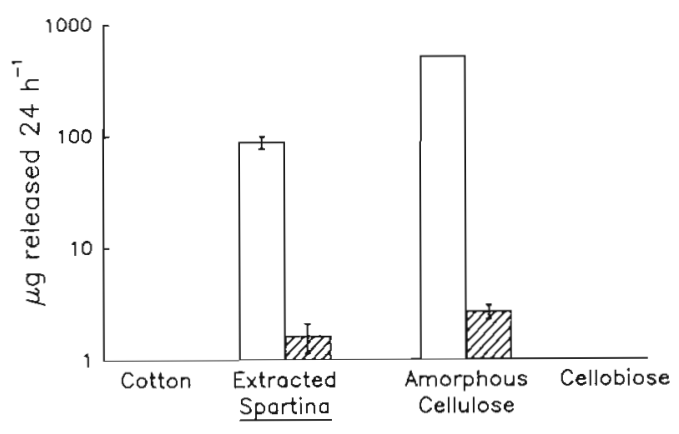

Fig. 7. Crassostrea virginica. Style cellulase activity. Mean ( \pm $1 \mathrm{SD}, \mathrm{n}=4$ ) $\mu \mathrm{g}$ total carbohydrate (glucose equivalents) (open bars), and $\mu \mathrm{g}$ glucose (bars with diagonal slashes), released during $24 \mathrm{~h}$ incubation from various cellulosic substrates per mg protein of style homogenate. Data from Newell \& Langdon (1986) 
ginica breaks down amorphous cellulose into soluble oligomers. These oligomers must be transported to the diverticula where intracellular $\beta$-glucosidase activity completes digestion, liberating glucose. However, cellulose is not efficiently used as a carbon source by C. virginica, possibly because intracellular $\beta$-glucosidase activity is rate limiting. Perhaps the main function of extracellular $\beta$-1,4-glucanase activity in $C$. virginica is the depolymerization of cellulosic cell walls of algae and cellulosic detritus particles with the consequent release and intracellular digestion of associated nutrients

Whereas Crassostrea virginica is predominantly distributed in sub-tidal zones of the mid-Atlantic coast of the USA, Geukensia demissa is restricted to high intertidal zones of marshes and brackish estuaries, sometimes being submerged for only $4 \mathrm{~h}$ per tidal cycle (Jordon \& Valiela 1982). Therefore, we compared the ability of mussels to use cellulose as a carbon source under simulated sub-tidal (continuous submergence) conditions versus simulated mid-intertidal ( $6 \mathrm{~h}$ submergence/6 h exposure) conditions (Kreeger 1986, Kreeger et al. 1988). Mussels held in the simulated mid-intertidal regime assimilated carbon from cellulose with an efficiency of $14.2 \%$ which was significantly higher than an efficiency of $9.2 \%$ for mussels held in the simulated subtidal conditions. On the basis of estimates given in Table 1 , cellulosic carbon could contribute $8.0 \%$ to the summer metabolic carbon requirements of mussels inhabiting the mid-intertidal zone of Canary Creek.

In vitro mussel cellulase activity has not been determined, but Brock et al. (1986) reported that $\beta-1,4$ glucanase activity in extracts of the diverticula of Geukensia demissa was about 2.5 times greater than in Crassostrea virginica, perhaps explaining the mussel's higher assimilation efficiency of carbon from cellulose compared with that for oysters. The higher carbon assimilation efficiency of intertidal mussels fed cellulose compared with that of sub-tidal mussels may be due to a prolonged gut residence time for ingested cellulose resulting in increased digestion efficiency. This hypothesis agrees with the suggestion of Bayne et al. (1988) that intertidal, suspension-feeding bivalve molluscs may physiologically compensate for reduced feeding periods by increasing gut residence time. Gillmor (1982) reported that intertidal populations of the ribbed mussel grew faster than subtidal populations. He suggested that higher growth rates of intertidal mussels were due to a requirement for a period of aerial exposure for co-ordination of digestive rhythms that, in turn, resulted in increased digestion efficiencies. Further experiments are required to determine the physiological basis of enhanced cellulose utilization in intertidal populations of $G$. demissa.

\section{NUTRITIONAL ROLE OF BACTERIA}

Although results from our experiments indicate insignificant direct utilization of cellulosic carbon by oysters in Canary Creek, bacteria associated with the decomposition of detrital material may facilitate transfer of carbon from particulate or dissolved sources to Crassostrea virginica. We examined this hypothesis by comparing ${ }^{14} \mathrm{C}$ assimilation efficiencies of $C$. virginica fed ${ }^{14} \mathrm{C}$-labelled lignocellulose alone with those of oysters fed on cellulosic material pre-incubated with cellulolytic bacteria isolated from Canary Creek. Initial experiments indicated that suspended cellulolytic bacteria were utilized by $C$. virginica with a ${ }^{14} \mathrm{C}$ assimilation efficiency of $52 \%$ (Crosby 1987, Crosby et al. in press). The bacteria/cellulose detrital complex was prepared by pre-incubating ${ }^{14} \mathrm{C}$-labelled cellulose with the cellulolytic strain of bacteria for 2 wk (Crosby 1987 , Crosby et al. in press). The measured ${ }^{14} \mathrm{C}$ assimilation efficiency of $10.3 \% \pm 6.7 \%(n=5)$ for oysters fed on the bacteria/cellulose detrital complex was significantly greater than the efficiency of $2.7 \% \pm 1.8$ ( $\mathrm{n}=$ 20) for oysters fed on ${ }^{14} \mathrm{C}$-labelled cellulose alone.

It is possible to estimate the contribution of attached bacteria to the carbon requirements of Crassostrea virginica and Geukensia demissa living in Canary Creek marsh during the summer (June through September) when water temperatures exceed $20^{\circ} \mathrm{C}$. Using a mean concentration for attached bacteria of $1.7 \times 10^{5} \mathrm{ml}^{-1}$ (Fig. 4) together with laboratory-determined assimilation efficiencies and respiration rates, we estimate that attached bacteria could contribute $2.1 \%$ to the metabolic carbon requirements of subtidal oysters and $5.2 \%$ to the metabolic carbon requirements of intertidal mussels over a complete tidal cycle (Table 1). It is apparent that cellulosic material (see previous section) and attached bacteria make a small contribution to the carbon requirements of intertidal mussels and an even smaller contribution to the requirements of subtidal oysters in Canary Creek (Table 1). Furthermore, the percentage contribution of cellulose and attached bacteria to the total carbon requirements of mussels and oysters will be even less than these estimates for metabolic carbon requirements because total carbon requirements are generally about $33 \%$ greater than a bivalve's metabolic carbon requirements (Bayne \& Newell 1983).

In other estuarine habitats, the contribution of attached bacteria to the carbon requirements of oysters and mussels may be higher than for populations inhabiting Canary Creek. For example, Crosby et al. (in press) estimated that attached bacteria could contribute $19.2 \%$ to the total carbon requirements of Crassostrea virginica inhabiting the Chesapeake Bay because of high suspended bacteria concentrations 
$\left(1 \times 10^{7}\right.$ cells $\left.\mathrm{ml}^{-1}\right)$ and a high proportion $(15 \%)$ of attached bacteria. Only $6 \%$ of the suspended bacteria in Canary Creek were attached. A similar low percentage $(<3 \%)$ of suspended bacteria were attached in the Great Sippewissett marsh (Kirchman et al. 1984).

We have compared the abilities of Crassostrea virginica and Geukensia demissa to remove free bacteria from marsh water collected from Canary Creek. We held individual mussels and oysters in upweller columns (Langdon \& Siegfried 1984) and added to the flowing seawater combinations of natural seston, free bacteria and 1.6 and $3.9 \mu \mathrm{m}$ diameter 'Fluoresbrite' polystyrene fluorescent microspheres (Polyscience Inc.). The concentrations of particles in water samples collected from below and above the bivalves in the upweller columns were determined with a model ZB Coulter Counter. For the enumeration of bacteria and microspheres, water samples were filtered onto $0.2 \mu \mathrm{m}$ 'Nuclepore' filters, bacteria were first stained with DAPI (Porter \& Feig 1980) and then bacteria and microspheres were counted directly using an epifluorescent microscope. Control treatments (empty mussel shells glued together) were included in the experiments to allow correction for changes in particle concentration due to particle settlement or other factors. We found that mussels removed unattached bacteria from Canary Creek water with $15.8 \%$ of the efficiency of removal for $3.9 \mu \mathrm{m}$ diameter microspheres, whereas oysters filtered unattached bacteria with an efficiency of only $5.0 \%$ that for $3.9 \mu \mathrm{m}$ microspheres (Fig. 8). Similarly, Riisgård (1988) reported that the ribbed mussel retained $<5 \mu \mathrm{m}$ sized particles more efficiently than the oyster although he did not obtain information on the retention of particles $<2 \mu \mathrm{m}$ in diameter which is a particle size more representative of the dimensions of free bacteria. Wright et al. (1982) did not determine retention efficiencies for oysters fed on free bacteria

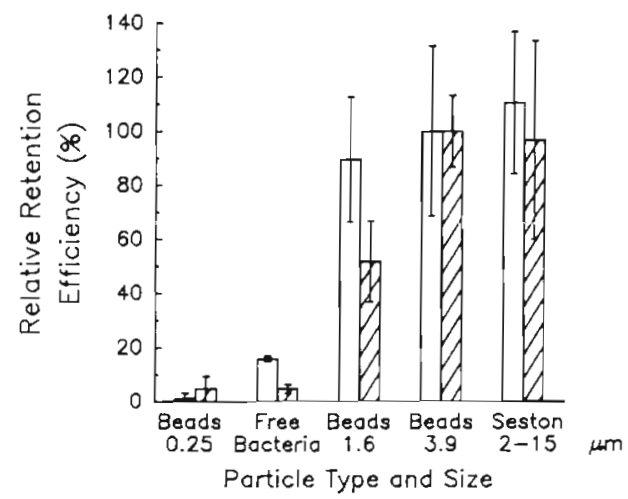

Fig. 8. Relative filtration efficiencies of Crassostrea virginica (bars with diagonal slashes) and Geukensia demissa (open bars). Retention efficiencies are mean values ( $\pm 1 \mathrm{SD}, \mathrm{n}=5$ ) for various sizes of suspended particles expressed relative to an assumed $1.00 \%$ retention efficiency for $3.9 \mu \mathrm{m}$ latex microspheres but reported that $G$. demissa retained total bacteria (attached and non-attached combined) from marsh water with $18.4 \%$ of the efficiency of retention for colloidal graphite (Aquadag) particles 1 to $2.3 \mu \mathrm{m}$ in size. The total bacteria retention efficiency of $G$. demissa reported by Wright and co-workers is comparable to our value of $15.8 \%$ for mussels fed on free bacteria (Fig. 8 ).

Using values for assimilation efficiencies of bacterial carbon (described above) for both oysters and mussels, unattached, free bacteria in Canary Creek could contribute $3.4 \%$ and $25.8 \%$ to the metabolic carbon requirements of subtidal oysters and intertidal mussels, respectively (Table 1). Therefore, unattached bacteria would appear to make a more significant contribution to the carbon requirements of mussels than to those of oysters.

Findlay \& Tenore (1982) used ${ }^{15} \mathrm{~N}$ tracer techniques to demonstrate that microbes associated with the breakdown of detritus could mediate the transfer of inorganic nitrogen from seawater to the polychaete Capitella capitata, thereby enriching the nitrogen content of the detrital particle. Using similar ${ }^{15} \mathrm{~N}$ tracer experiments, we demonstrated that cellulolytic bacteria, associated with the breakdown of prepared Spartina alterniflora lignocellulosic material, incorporated inorganic nitrogen from seawater. However, oysters fed on the detrital complex only absorbed ${ }^{15} \mathrm{~N}$ associated with the particle with an efficiency of $3.5 \% \pm$ $2.3 \%(n=5)$ (Crosby et al. in press). Therefore, most of the particulate nitrogen associated with the detrital complex was nutritionally unavailable to the oyster. Only $6 \%$ of detrital ${ }^{15} \mathrm{~N}$ was estimated to be associated with bacterial cells. If the oyster's assimilation efficiencies for bacterial carbon and nitrogen are assumed to be similar at $52 \%$ (Crosby et al. in press), utilization of bacteria cellular nitrogen alone could account for almost all of the oyster's observed absorption of nitrogen from the detrital complex.

A possible explanation for the oyster's low absorption efficiency for detrital nitrogen is that the majority $(95 \%)$ of the nitrogen associated with sediments is refractory and not metabolizable by invertebrates (Rice et al. 1986). Rice (1982) and Rice \& Hanson (1984) suggested that refractory detrital nitrogen may be covalently bound as complex macromolecular material produced by condensation reactions between microbial proteinaceous exudates and reactive phenols or carbohydrates generated in the decomposing detritus matrix. Harvey \& Luoma (1984) reported that sedimentbound and dissolved bacterial exopolymers did not appear to be directly metabolized by the deposit-feeding clam Macoma balthica. Nutritionally available nitrogen of detrital particles would, therefore, appear to be primarily associated with bacteria cells. 
The estimated contributions of bacteria in meeting metabolic nitrogen requirements are $10 \%$ (attached bacteria) and $16.7 \%$ (unattached bacteria) for subtidal oysters compared with $11 \%$ (attached) and $60 \%$ (unattached bacteria) for intertidal Geukensia demissa in Canary Creek marsh during the summer (Table 1). A similarly significant contribution of bacteria to the nitrogen requirements of bivalves has been reported by Newell \& Field (1983a, b) who estimated that suspended bacteria present in South African kelp beds provided $73 \%$ of the nitrogen, but only $9 \%$ of the carbon, required by bivalve suspension feeders. However, it is only in certain environments, such as eutrophic estuaries (Ducklow et al. 1988), kelp beds, and marshes that bacteria concentrations are sufficiently great for bacteria to contribute significantly to the nutrition of suspension-feeding bivalves. In contrast, bacteria are generally less abundant in open coastal and oceanic waters (Coffin \& Sharp 1987) and in such habitats bacterial nitrogen is unlikely to be nutritionally significant for bivalves.

\section{OTHER SOURCES OF NUTRITION}

The results of the studies reviewed here indicate that the ribbed mussel, Geukensia demissa, is better able to filter bacteria from suspension and assimilate carbon from cellulosic detritus compared with the oyster, Crassostrea virginica. As a result of these physiological processes, $G$. demissa can potentially derive a greater proportion of its carbon and nitrogen requirements from cellulose and bacteria than the oyster. This conclusion is supported by stable isotope analyses which indicate that material derived from Spartina alterniflora is a more important dietary constituent for $G$. demissa than for C. virginica (Montague et al. 1981, Peterson et al. 1985, 1986). However, we estimate that direct utilization of cellulose and bacteria only accounts for $40 \%$ of the summer metabolic carbon requirements of mussels inhabiting Canary Creek marsh with bacteria also supplying $71 \%$ of the mussel's metabolic nitrogen requirements. This estimate of cellulose/bacterial carbon utilization by $G$. demissa is in agreement with our finding, based on stable isotope anaiysis, that $S$. alterniflora is providing between 30 and $50 \%$ of the mussel's carbon requirement for growth (Fig. 5). In contrast Peterson et al. (1985) reported that mussels living in the inner regions of the Great Sippewissett marsh (Mass., USA) obtain at least $80 \%$ of their carbon requirements from food originating from $S$. alterniflora (Fig. 5). This high contribution from Spartina-derived material may be due to mussels being exposed to concentrations of cellulosic detritus and bacteria that are higher in the Great Sippewissett marsh than those we measured in
Canary Creek marsh. Bacteria concentrations in the Great Sippewissett marsh vary according to tide and season but maximum summer concentrations $\left(3.2 \times 10^{6}\right.$ cells $\mathrm{ml}^{-1}$; Kirchman et al. 1984) are lower than summer concentrations in Canary Creek marsh. Kirchman et al. (1984) estimated that bacteria in the Great Sippewissett marsh supplied less than $10 \%$ of the carbon required by $G$. demissa for growth during the summer.

Unfortunately, there are no reported data on cellulose concentrations for the Sippewissett marsh to compare with our data for Canary Creek and so it is impossible to estimate direct utilization of cellulosic carbon by bivalves in this marsh. Indirect utilization of material derived from Spartina alterniflora via consumption of nanozooplankton may be an important source of nutrition for mussels in the Great Sippewissett marsh, explaining the stable isotope signatures obtained by Peterson et al. (1986). Nanociliates and flagellates are important components of the nanozooplankton of estuarine waters and have been shown to feed primarily on bacteria (Fenchel 1982, Sherr et al. 1986, 1987). In salt marshes, Benner et al. (1988) demonstrated that protozoans are important consumers of bacteria associated with the decomposition of lignocellulosic material derived from $S$. alterniflora. Nanociliates and flagellates which are 2 to $20 \mu \mathrm{m}$ in size can be more efficiently retained by suspension-feeding bivalves than unattached bacteria and hence may be an important link in the transfer of nutrients from bacteria to bivalves (Sherr et al. 1986). We know of no reported concentrations of nanozooplankton in Great Sippewissett marsh; however, Sherr et al. (1986) have reported that ciliates and flagellates attained a carbon biomass of 12.2 and $9.3 \mu \mathrm{g} \mathrm{Cl}^{-1}$, respectively, during August in tidal creeks draining the upper Duplin River salt-marsh in Georgia. If we assume that, (a) such concentrations of nanozooplankton are typical of marsh systems, (b) nanozooplankton can be filtered from suspension with $100 \%$ efficiency by bivalves and, (c) cellular carbon is absorbed with $75 \%$ efficiency (a typical efficiency for phytoplankton cells; Bayne and Newell 1983), we estimate, using additional data in Table 1, that nanozooplankton could contribute $15 \%$ and $37 \%$ to the summer metabolic carbon requirements of oysters and mussels, respectively, in Canary Creek.

Little is known of the potential contribution of dissolved organic matter (DOM) to the nutrition of marshinhabiting bivalves. Concentrations of DOM may be as high as $9 \mathrm{mg} \mathrm{Cl}^{-1}$ in some marshes, i.e. 10 to 20 times that present in the open ocean (Pomeroy \& Imberger 1981). Most of this material is thought to be refractory although a labile fraction is available to bacteria (Wiegert et al. 1981) and possibly to mussels and oysters which have been shown to absorb dissolved nutrients, such as amino acids, directly from seawater 
(Wright 1982). Manahan et al. (1983) estimated that uptake of amino acids at ambient concentrations in seawater, could meet $34 \%$ of the metabolic requirements of the mussel Mytilus edulis.

In summary, it is apparent that mussels and oysters inhabiting Canary Creek marsh must utilize food sources in addition to cellulose and bacteria in order to satisfy their summer carbon and nitrogen requirements. This conclusion agrees with that of Peterson et al. (1985, 1986) who determined that mussels in the Great Sippewissett marsh use a mixture of food sources to meet their nutritional requirements, with the proportion derived from Spartina alterniflora varying according to the mussel's location in the marsh and season.

Phytoplankton is probably the major source of nutrition for marsh-inhabiting bivalves, especially during periods of high phytoplankton abundance. During periods of low phytoplankton abundance, unattached bacteria may be an important source of nitrogen and carbon for mussels, and to a lesser extent for oysters. Cellulose appears to be a less important source of carbon than bacteria for mussels and oysters inhabiting Canary Creek during the summer, but nonetheless cellulose may indirectly contribute to their carbon requirements by acting as a carbon source for cellulolytic bacteria and perhaps nanozooplankton. This indirect contribution of material derived from Spartina alterniflora to the nutrition of bivalves inhabiting marshes would explain the results of stable isotope analyses which have indicated the importance of $S$. alterniflora in mussel nutrition.

Acknowledgements. This research was supported in part by grants (\# OCE-8400264) from the Biological Oceanography division of the National Science Foundation to R.I.E. Newell, C. J. Langdon and H. W. Ducklow and a University of Maryland Sea Grant (NA84-AAD00014) to R.I.E. Newell and T J. Jones. We thank M. P. Crosby and D. A. Kreeger for their contributions to the research on which this paper is based.

\section{LITERATURE CITED}

Bayne, B. L. (1976). Aspects of reproduction in bivalve molluscs. in: Wiley, M. (ed.) Estuarine processes, Vol. 1., Uses, stresses, and adaptation to the estuary. Academic Press, New York, p. 432-448

Bayne, B. L., Newell, R. C. (1983). Physiological energetics of marine molluscs. In: Saleuddin, A.S.M. Wilbur, K. M. (eds.) The Mollusca. Vol. 4. Physiology, Part 1. Academic Press, New York, p. 407-515

Bayne, B. L., Hawkins, A. J. S., Navarro, E. (1988). Feeding and digestion in suspension-feeding bivalve molluscs: the relevance of physiological compensations. Am. Zool. 28: $147-159$

Benner, R., Newell, S. Y., MacCubbin, A. E., Hodson, R. E. (1984). Relative contributions of bacteria and fungi to rates of degradation of lignocellulosic detritus in salt-marsh sediments. Appl environ. Microbiol. 48: 36-40
Benner, R., Lay, J., K'nees, E., Hodson, R. E. (1988). Carbon conversion efficiencies for bacterial growth on lignocellulose: implications for detritus based food webs. Limnol. Oceanogr. 33: 1514-1526

Berg, J. A., Newell, R. I. E. (1986). Temporal and spatial variations of seston as a food resource available to the oyster Crassostrea virginica. Estuar cstl Shelf Sci. 23: 375-386

Brock, V., Kennedy, V S., Brock, A. (1986). Temperature dependency of carbohydrase activity in the hepatopancreas of thirteen estuarine and coastal bivalve species from the North American east coast. J. exp. mar. Biol. Ecol. 103: $87-101$

Crosby, M. P. (1987). Utilization of detrital complexes by the oyster Crassostrea virginica (Gmelin). Ph.D. thesis, University of Maryland, College Park

Crosby, M. P., Langdon, C. J., Newell, R. I. E. (1989). Importance of refractory plant material to the carbon budget of the oyster Crassostrea virginica. Mar. Biol. 100: $343-352$

Crosby, M. P., Newell, R. I. E., Langdon, C. J. (in press). Bacterial mediation in the utilization of carbon and nitrogen from detrital complexes by the American oyster, Crassostrea virginica. Limnol. Oceanogr.

Coffin, R. B., Sharp, J. H. (1987). Microbial trophodynamics in the Delaware Estuary. Mar. Ecol. Prog. Ser. 41 253-266

Ducklow, H. W (1982). Chesapeake Bay nutrient and plankton dynamics. I. Bacterial biomass and production during spring tidal destratification in the York River Estuary, Virginia. Limnol. Oceanogr. 27: 651-659

Ducklow, H. W., Peele, E. A., Hill, S. M., Quinby, H. L. (1988) Fluxes of carbon, nitrogen, and oxygen through estuarine bacterioplankton. In: Lynch, M. (ed.) Perspectives in Chesapeake Bay research. Chesapeake Bay Research Consortium, Gloucester Point, VA, p. 511-523

Epifanio, C. E. (1982). Phytoplankton and yeast as foods for juvenile bivalves: a review of research at the University of Delaware. In: Pruder, G. D., Langdon, C. J., Conklin, D. E. (eds.) Proc of the Second International Conference on Aquaculture Nutrition. Louisiana State University, Baton. Rouge, p. 292-304

Eppley, R. W. (1972). Temperature and phytoplankton production in the sea. Fish. Bull. U. S. 70: 1063-1085

Fenchel, T (1982). Ecology of heterotrophic microflagellates. I. Some important forms and their functional morphology. Mar. Ecol. Prog. Ser. 8: 211-223

Fenchel, T., Blackburn, T. M. (1979). Bacteria and mineral cycling. Academic Press, London

Fielding, P. J., Harris, J. M., Lucas, M. I., Cook, P. A. (1986). Implications for the assessment of crystalline style activity in bivalves when using the Bernfield and Nelson-Somogyi assays for reducing sugars. J. exp. mar Biol. Ecol. 101: 269-284

Findlay, S., Tenore, K, (1982). Nitrogen source for a detritivore: detritus substrate versus associated microbes. Science 218: $371-373$

Gillmor, R. B. (1982). Assessment of intertidal growth and capacity adaptations in suspension-feeding bivalves. Mar. Biol. 68: 277-280

Harvey, R. W.. Luoma, S. N. (1984). The role of bacterial exopolymer and suspended bacteria in the nutrition of the deposit-feeding clam, Macoma balthica. J. mar. Res. 42: 957-968

Heinle, D. R., Flemer, D. A. (1976). Flows of materials between poorly flooded tidal marshes and an estuary. Mar. Biol. 35: $359-373$ 
Jordan, T E., Valiela, I. (1982). A nitrogen budget of the ribbed mussel, Geukensia demissa, and its significance in the nitrogen flow in a New England salt marsh. Limnol. Oceanogr 27: 75-90

Kirby-Smith, W. W (1976). The detritus problem and the feeding and digestion of an estuarine organism. In: Wiley, M. (ed.) Estuarine processes, Vol. I. Academic Press, New York, p. 469-479

Kirchman, D., Peterson, B., Juers, D. (1984). Bacterial growth and tidal variation in bacterial abundance in the Great Sippewissett salt marsh. Mar. Ecol. Prog. Ser 19: 247-259

Kreeger, D. A. (1986). Utilization of refractory cellulosic material derived from Spartina alterniflora (Loisel.) by the ribbed mussel Geukensia demissa (Dillwyn). M. S. thesis, University of Delaware, Lewes

Kreeger, D. A., Langdon, C. J, Newell, R. I. E. (1988). Utilization of refractory cellulosic carbon derived from Spartina alterniflora by the ribbed mussel Geukensia demissa. Mar. Ecol. Prog. Ser. 42: 171-179

Kuenzler, E. J. (1961). Structure and energy flow of a mussel population in a Georgia salt marsh. Limnol. Oceanogr. 6: 191-204

Langdon, C. J., Siegfried, C. A. (1984). Progress in the development of artificial diets for bivalve suspension-feeders. Aquaculture 39: 135-153

Lucas, M. I., Newell, R. C. (1984). Utilization of saltmarsh detritus by two estuarine bivalves: carbohydrase activity of crystalline style enzymes of the oyster Crassostrea virginica (Gmelin) and the mussel Geukensia demissa (Dillwyn). Mar. Biol. Lett. 5: 275-290

Maccubbin, A. E., Hodson, R. E. (1980). Mineralization of detrital lignocelluloses by salt marsh sediment microflora. Appl. environ. Microbiol. 40: 735-740

Manahan, D. T., Wright, S. H., Stephens, G. C. (1983). Simultaneous determination of net uptake of 16 amino acids by a marine bivalve. Am. J. Physiol. 244: R 832-838

Mayasich, S. A., Smucker, R. A. (1986). Glycosidases in the American oyster, Crassostrea virginica Gmelin, digestive tract. J. exp. mar. Biol. Ecol. 95: 95-98

McIntire, G. L., Dunstan, W M. (1976). Non-structural carbohydrates in Spartina alterniflora Loisel. Botanica mar 19: 93-96

Montague, C. L., Bunker, S. M., Haines, E. B., Pace, M. L., Wetzel, R. L. (1981). Aquatic macroconsumers. In: Pomeroy, L. R., Weigert, R. G. (eds.) The ecology of a salt marsh. Springer-Verlag, New York, p. 68-86

Nagata, T (1986). Carbon and nitrogen content of natural planktonic bacteria. Appl. environ. Microbiol. 52: 28-32

Newell, R. C. (1979). Biology of intertidal animals. Marine Ecological Surveys Ltd, Faversham

Newell, R. C., Field, J. G. (1983a). The contribution of bacteria and detritus to carbon and nitrogen flow in a benthic community. Mar. Biol. Lett. 4: 23-36

Newell, R. C., Field, J. G. (1983b). Relative flux of carbon and nitrogen in a kelp dominated system. Mar. Biol. Lett. 4: 249-257

Newell, R. I. E., Langdon, C. J. (1986). Digestion and absorption of refractory carbon from Spartina alterniflora (Loisel) by the oyster, Crassostrea virginica (Gmelin). Mar. Ecol. Prog. Ser 34: 105-115

Newell, S. Y., Fallon, R. D., Cal Rodriguez, R. M., Groene, L. G. (1985). Influence of rain, tidal wetting and relative humidity on release of carbon dioxide by standing-dead salt-marsh plants. Oecologia (Berl.) 68: 73-79

Peterson, B. J., Howarth, R. W., Garritt, R. H. (1985). Multiple stable isotopes used to trace the flow of organic matter in estuarine food webs. Science 227: 1361-1363
Peterson, B. J., Howarth, R. W., Garritt, R. H. (1986). Sulfur and carbon isotopes as tracers of salt-marsh organic matter flow. Ecology 67: 865-874

Pickral, J. C., Odum, W. E. (1976). Benthic detritus in a saltmarsh tidal creek. In: Wiley, M. (ed.) Estuarine processes. Academic Press, New York, p. 280-292

Pomeroy, L. R., Imberger, J. (1981). The physical and chemical environment. In: Pomeroy, L. R., Wiegert, R. G. (eds.) The ecology of a salt marsh. Springer-Verlag, New York, p. 21-36

Porter, K. G., Feig, Y S. (1980). The use of DAPI for identifying and counting aquatic microflora. Limnol. Oceanogr. 25: $943-948$

Rice, D. L. (1982). The detritus problem: new observations and perspectives from organic geochemistry. Mar. Ecol. Prog. Ser. 9: 153-162

Rice, D. L., Bianchi, T. S., Roper, E. H. (1986). Experimental studies of sediment reworking and growth of Scoloplos spp. (Orbiniidae: Polychaeta). Mar. Ecol. Prog. Ser. 30: 9-19

Rice, D. L., Hanson, R. B. (1984). A kinetic model for detritus nitrogen: role of the associated bacteria nitrogen accumulation. Bull. mar. Sci. 35: 327-340

Riisgård, H. U. (1988). Efficiency of particle retention and filtration rate in 6 species of Northeast American bivalves. Mar. Ecol. Prog. Ser. 45: 217-223

Sastry, A. N. (1979). Pelecypoda (excluding Ostreidae). In: Giese, A. C., Pearse, J. S. (eds.) Reproduction of marine invertebrates. Vol. V. Academic Press, New York, p. $113-292$

Sherr, B. F., Sherr, E. B., Fallon, R. D. (1987). Use of monodispersed, fluorescently labeled bacteria to estimate in situ protozoan bacterivory. Appl. environ. Microbiol. 53: 958-965

Sherr, E. B., Sherr, B. F., Fallon, R. D., Newell, S. Y. (1986). Small, aloricate ciliates as a major component of the marine heterotrophic nanoplankton. Limnol. Oceanogr. 31. $177-183$

Smith, K. K., Good, R. E., Good, N. F. (1979). Production dynamics for above and below ground components of a New Jersey, Spartina alterniflora tidal marsh. Estuar cstl Shelf Sci. 9: 189-201

Squiers, E. R., Good, R. E. (1974). Seasonal changes in the productivity, caloric content and chemical composition of a population of salt marsh cordgrass (Spartina alterniflora). Chesapeake Sci. 15: 63-71

Strickland, J. D. H., Parsons, T R. (1972). A practical handbook of seawater analysis. Bull. Fish. Res. Bd Can. 167

Stuart, V., Field, J. G., Newell, R. C. (1982). Evidence for absorbtion of kelp detritus by the mussel Aulacomya ater using a new ${ }^{51} \mathrm{Cr}$-labelled microsphere technique. Mar. Ecol. Prog. Ser. 9: 263-271

Webb, K. L., Chu, F. L. (1982). Phytoplankton as a food source for bivalvae larvae. In: Pruder, G. D., Langdon, C. J., Conklin, D.E. (eds.) Proc. of the Second International Conference on Aquaculture Nutrition. Louisiana State University, Baton Rouge, p. 272-291

Widdows, J., Bayne, B. L., Livingstone, D. R., Newell, R. I. E., Donkin, P. (1979). Physiological and biochemical responses of bivalve molluscs to exposure to air. Comp. Biochem. Physiol. 62A: 301-308

Wiegert, R. G., Pomeroy, L. R., Wibe, W. J. (1981). Ecology of salt marshes: an introduction. In: Pomeroy, L. R., Wiegert, R. G. (eds) The ecology of a salt marsh. Springer-Verlag, New York, p. 3-19

Williams, P. (1981). Detritus utilization by Mytilus edulis Estuar. cstl Shelf Sci. 12: 739-746 
Wright, R. T., Coffin, R. B., Ersing, C. P., Pearson, D. (1982). Field and laboratory measurements of bivalve filtration of natural marine bacterioplankton. Limnol. Oceanogr. 27: 91-98

Wright, S. H. (1982). A nutritional role for amino acid transport

This review was presented by Professor C. H. Peterson,

Morehead City, N. Carolina, USA in filter-feeding marine invertebrates. Am. Zool. 22 621-634

Zeitzschel, B. (1970). The quantity, composition and distribution of suspended particulate matter in the Gulf of California. Mar Biol 7: 305-318

Manuscript first received: November 10,1988

Revised version accepted: August 23, 1989 